\title{
Why Individual Freedom and the Autonomy of Law Stand or Fall Together
}

\author{
Bjarne Melkevik ${ }^{1}$ \\ Åsbjørn Melkevik²
}

\section{Two Kinds of Autonomy - Legal and Individual}

There is, in legal philosophy, an ongoing debate about the autonomy of law, that is, about the extent to which law is distinguishable from some other phenomena. The dominant views, today, all understand law as fulfilling a certain instrumental role. Justice and efficacy, then, are probably the most common relational others to law. For example, it is common to say that the law should further a certain understanding of distributive justice - this is the view preferred by philosophers such as John Rawls and Ronald Dworkin. Others have argued for the efficacy of the law as with the law-and-economics approach most famously championed by Judges Frank Easterbrook and Richard Posner. This paper argues for a radically different understanding of the law, as it explains why the law should indeed be autonomous. The question, however, is not whether the law is actually autonomous or not - it is obviously not, as the law is too often the plaything of various lawgivers. The real question is the following - do we want to be autonomous, as individuals? The answer is obviously yes, individual freedom being a universal value, and therefore, this paper argues, the law should also be autonomous. There is, as we will

\footnotetext{
${ }^{1}$ Doctorat d'État in Legal Science at University Paris 2 - France. Professor at the Faculté de Droit Université Laval /Canada.

${ }^{2}$ Ph.D. in political studies, Queen`s University. Post-Doctoral Fellow-in-Residence at Harvard University.
} 


\section{THISTA ACADÊMICA FACULDADE DE DIRETIO DO DECIFE}

show, a parallel between individual autonomy and the autonomy of law - these two kinds of autonomy stand or fall together.

We follow the Roman tradition, and more precisely Cicero, in understanding the law as the appropriate starting point for our understanding of proper human conduct "the most learned men", said Cicero, "have chosen to take law as their starting point." Like Cicero, we are inclined to think these learned men were right, since law is indeed the highest reason, "which enjoins what ought to be done and forbids the opposite." Of course, there is no denying that legality is a condition of efficacy, and that it also leads to justice, which, after all, is essential for the welfare of mankind. Yet something will inevitably be amiss if we understand law only in instrumental terms. The autonomy of law is perhaps best understood as a debate about the intelligence of legal action. Law is a practical art, which often becomes stained once we begin to pursue extra-legal objectives - and this stain, unfortunately, also affects our freedoms as individuals.

The concept of law, of course, is rather ambiguous. Let us accordingly begin by saying a few words about that concept. Law is a practical question - it is about the settlement of conflicts, be it inside or outside a courtroom. The sources of authority normally used to settle such conflicts a real so called law. But, in the end, the question is always about people having to settle conflicts. In other words, law is a mechanism of cooperation, and thus our understanding of the law is very much influenced by the ways in which we think such conflicts should be handled. As Christopher Tomlins explained, "the meaning and character we ascribe to law will necessarily vary according to the relations we identify as relevant, the others that we recognize, and our ways of characterizing them." The legal theory this paper argues for says that conflicts are best handled by the people themselves, not immediately by judges or lawgivers.

We will illustrate our thesis about the autonomy of law by, first, explaining why we should want law to be autonomous, using the two historical examples of the Roman law and the Viking law, and second, by arguing for the lawyer's law against the lawgiver's law. The goal of this paper is quite simple - we want to show that individual

\footnotetext{
${ }^{3}$ Cicero, De Legibus (The Laws), 1.18.

${ }^{4}$ Christopher Tomlins, “How Autonomous Is Law?”, Annu. Rev. Law Soc. Sci., Vol. 3, 2007, p. 46.
} 


\section{REVISTA ACADÊMICA

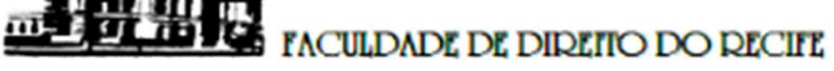

autonomy and the autonomy of law are matching concepts, that is, we cannot truly have one without the other.

\section{Why Do We Want the Law to Be Autonomous?}

Let us begin with the following question - why do we want the law to be autonomous? The simplest answer is that we, as individuals, also want to be autonomous. In other words, for us to be autonomous, we must first ensure that the law is also autonomous to a certain degree. This, then, leads us to another question - why do individual autonomy and the autonomy of law go hand in hand?

Consider the following imagined case. You buy a house in a good neighbourhood to raise your family. Surely, you want some security from heteronymous forces- that is, you do not want the new television you just bought to get stolen, you do not want your daughter to get mugged, and you do not want the newly-elected government to enact a rule forcing you to demolish your garage because your neighbour is a minister who does not like to have your garage standing so close to his property. To put it simply, your autonomy and the autonomy of your family should not be a playfield for heteronymous forces. Not only will you oppose such illegitimate forces, but you will probably also be wary of legitimate sources of authority. Even in a democracy, the majority of people should not be free to do as they will with the law. We all cherish our own security, which includes something akin to "legal security" - and this security can seriously be compromised when lawgivers use the law to achieve their own personal goals, or some other goals which are not your own.

The autonomy of law, therefore, is not an abstract problem only relevant for a few legal philosophers, judges, and lawyers. It is rather a question that concerns everyone. When the law is an instrument for a few lawgivers, we argue, the people's freedom and security will immediately be compromised. The general problem of the autonomy of law can best be illustrated by looking at a few historical examples. Consider, first, the Twelve Tables, which is the foundation of Roman law, written around 450 B.C., and which, through the definitions of some private rights and legal procedures, was a true declaration 


\section{REVISTA ACADÊMICA FACULDADE DE DIRETIO DO DECIFE}

of freedom for the Roman people.The seventh law of the first table is particularly important - it says the following:

"When litigants wish to settle their dispute among themselves, even while they are on their way to appear before the Prætor, they shall have the right to make peace; and whatever agreement they enter into, it shall be considered just, and shall be confirmed."

The Roman people had the right to make peace by themselves. The law, in this case, is under the autonomy of the people. Individuals can call upon the law, and the law is there for them to use for their benefit. What is important, hence, is that it is the people themselves who own, create, make use of, and benefit from the law. The law is not used to govern, to rule, or to have, as today, a hold on the people. The law is rather used as a method to establish peace, resolve problems, and guarantee ordered relations between individuals. If Romans use the law by themselves to make peace, without having to appear before the Prætor, then we will say such a law duly respects the autonomy of the Romans. In other words, the law is theirs, as it does not follow goals which are not their own. The Romans were accordingly, properly speaking, the owners of the law. Moreover, Titus Livy, the famous Roman historian, once described the creation of the Twelve Tables as follows: "every citizen should quietly consider each point, then talk it over with his friends, and, finally, bring forward for public discussion any additions or subtractions which seemed desirable. ${ }^{6}$,

Not only did the Twelve Tables establish the power of the Roman people to solve problems by their own, but the Tables were also a creation of the people. Let us now examine a second similar example, which we take from the Viking era. Medieval Scandinavians are often portrayed as bloody brutes. This, however, is incorrect - though it is true, their raids were somewhat gory businesses.

For instance, in Egil's Saga, the hero, Egil Skallagrímsson, once says, "Let us go back to the farm and acquit ourselves like true warriors: kill everyone we can catch and take all the valuables we can carry. ${ }^{7}$ " Yet this is only one side of the Vikings - and

\footnotetext{
${ }^{5}$ Lex XII Tabularum, I.7.

${ }^{6}$ Titus Livy, Ab Urbe Condita Libri (The History of Rome), 3.34.

${ }^{7}$ Egil's Saga, 58.30 .
} 


\section{THISTA ACADÊMICA

certainly not the most important one. We often forget that the Vikings had probably the most comprehensive system of private law ever created $^{8}$.

Njal's Saga, more particularly, is a great judicial saga in which most of the action takes place in the Law Council. It pictures a community of free people who will not bend before anyone except the law they agreed to accept as theirs. When Njal Porgeirsson's allies proposed to put an end to their lawsuits against their enemies using force, Njal responded the following:

"That you must not do, for it will not do to be without law in the land. [...] The best step, it seems to me, is for us to call a meeting of all the chieftains to talk about it. The future laws for Rome should be such as would appear to have been no less unanimously proposed by the people themselves than ratified by them on the proposal of others."

The Vikings, then, understood the law as a simple way to seek peace. They decided together, judged together, and they stood and fell together. We think this is the proper way to understand law in general. The law should not be a mere instrument to achieve some shady goals, or even to promote some worthy causes. In the end, when the law is not autonomous, it is always used to control the people so to make them act and think as the lawgivers desire. This, of course, is not what a free people should strive for. Both the Roman law and the Viking law were probably more democratic than most, if not all, so-called democracies today, as they understood one simple lesson - if a people is to be free, and if individuals are to be treated as autonomous beings, then the law should also be autonomous, unconstrained by heteronymous forces.

\section{The Lawgivers' Law and the Lawyer's Law}

We now turn to more controversial matters - the problem being, as we said, that the law is obviously not autonomous today. Lawgivers, such as politicians, civil servants, and judges, we argue, represent the greatest peril the autonomy of the people must face.

${ }^{8}$ David D.Friedman, The Machinery of Freedom: Guide to a Radical Capitalism, La Salle, Open Court Publishing Company, 1989, ch. 44, "Private Law Enforcement, Medieval Iceland, and Libertarianism".

${ }^{9}$ Njal's Saga, 97. 


\section{Tis REVISTA ACADÊMICA FACULDADE DE DIRETIO DO DECIFE}

If individual autonomy is to be preserved, the power granted to these lawgivers must inevitably be limited, perhaps dramatically. This, we think, can best be realized with strong lawyers and with procedural constraints, permitting lawyers to force judges and the offices of the lawgivers in general to bend under the autonomy of law.

Consider, more specifically, judges who currently hold a tremendous amount of power. The usual contemporary precepts explaining how to domesticate the function of the judge cannot work in our modernity, and indeed they have too often failed. It is important, therefore, to know how ancient laws acknowledged the danger of the judge, and how they acted to prevent any wrongful behaviour. Recall that, in Roman law, the office of judge was prohibited to professional jurists and that it was only the "honest citizens of Rome" that could serve as judges. Similarly, in the Middle Age, there was the well-known precept of the "right to be judged by one's peers", that is the "per judicium parium suorum", which kept away professional lawyers from the judging process.

These simple yet effective precepts of old are, we think, much more suited to our modernity than most modern legal theories will admit today - i.e. these precepts further the main argument of this paper, which is that the people themselves should be the owners of the law. For such an ownership to happen, it is imperative that the people do not give away their prerogatives to judges, even if these judges are presumed to interpret the law according to a community - like Ronald Dworkin famously proposed with his theory of law as integrity. If the law is to be truly "integral" to a community, it is best that the people themselves own such law.

We should imperatively reject the classical model equating the "Judge" with the "Law", as in the Judgement of Solomon where the judge is pictured as an incarnation of wisdom and justice ${ }^{10}$. Cicero, for example, once said that "a magistrate is a speaking law, and law a silent magistrate. ${ }^{11}$ " We disagree so to rather agree with Montesquieu's famous phrase, which said that a judge is "no more than the mouth that pronounces the words of the law ${ }^{12}$ ". The law, indeed, belongs to the people, and it is accordingly for them to speak what is the law.

\footnotetext{
${ }^{10} 1$ Kings 3:16-28.

${ }^{11}$ Cicero, De Legibus (The Laws), 3.2.

${ }^{12}$ Montesquieu, The Spirit of the Law, 11.6
} 


\section{REVISTA ACADÊMICA

We personally prefer to understand the law from the standpoint of acting and engaged lawyers, much like in Njal's Saga. Lon Fuller once noticed how strange it is that legal philosophy almost entirely neglects the activity of lawyers, so to rather focus on the usual favourite themes of jurisprudence - e.g. theories about state-made law, the judicial process, the interpretation of statutes, the interaction of state-made law and custom ${ }^{13}$. Such a neglect of the activity of lawyers, we think, unnecessarily impoverishes contemporary legal philosophy. Indeed, such a focus on state-made law does not do justice to law as a practical art, the goal of which is to resolve conflicts. We should never underestimate the capacity of the people to resolve conflicts by themselves, especially when assisted by experienced lawyers who do not need, most of the time, the input of the lawgivers.

Fifty years ago, writing about rampant economic crimes in the Russian Republic that were such a problem that they were deemed to warrant the application of the death penalty, Harold Berman wrote the following - "it is the lawyers who understand best of all, perhaps, the integrity of law, the universality of legal standards - in other words, the threat to legality in general which is posed by any particular infringement of legality. ${ }^{14 \text { ", }}$ The same argument, we think, can be made for the autonomy of law - that is to say, it is the lawyers who understand best of all such autonomy. Once we begin to understand the law purely in instrumental terms, notwithstanding how noble are the objectives pursued, it is then our autonomy as individuals that will soon be compromised - and lawyers are the first who will have to deal with the consequences of any abuse.

Legal philosophy, hence, should be much more concerned with the activity of the lawyers, because they are our best hope to force judges and the offices of the lawgivers to bend under the autonomy of law. Let the people make peace by themselves. Fuller said that if we are to understand the "effort that goes into creating and maintaining a system for directing human conduct by rules", we need to put ourselves in the place of judges and legislative draftsmen ${ }^{15}$. It is certainly useful to consider the problems lawgivers face,

\footnotetext{
${ }^{13}$ Lon Fuller, “American Legal Philosophy at Mid-Century: A Review of Edwin W. Patterson's Jurisprudence, Men and Ideas of the Law", Journal of Legal Education, Vol. 6, No. 4, 1954, pp. 476f.

${ }^{14}$ Harold Berman, "The Struggle of Soviet Jurists Against a Return to Stalinist Terror", Slavic Review, Vol. 22, 1963, p. 315.

${ }^{15}$ Lon Fuller, The Morality of Law, New Haven, YaleUniversity Press, 1969, pp. 106f.
} 


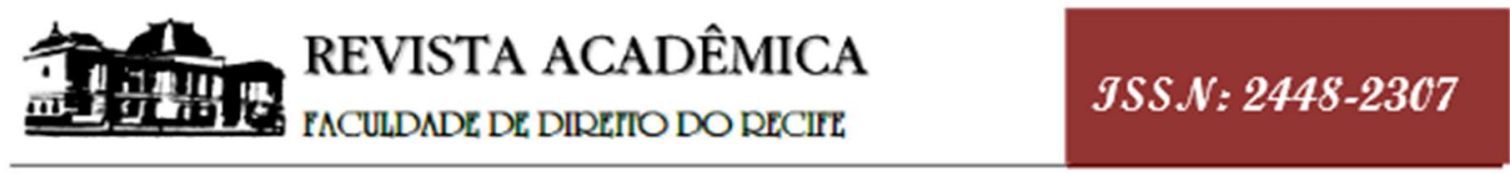

but it is perhaps more useful to consider the viewpoint of lawyers, who are, afterwards, the ones having to deal with such law.

\section{Three Lessons About the Autonomy of Law}

In conclusion, let us propose the following three lessons.

First, you are and you should be, together with others, the "owner" of the law.

Second, using the law, you should be able to resolve the problems you encounter.

Third, you should be able to find the reason to accept a judgement in law - and for this to happen, of course, the law cannot be entirely disconnected from your own autonomy.

The most important lesson is the first one - that is, we are all owners of the law, and because we are all autonomous beings, the law should be autonomous as well. Though this conclusion may seem simple, it is in fact only strengthen by its simplicity this is the true ideal of a free people, to live by rules which are their own. 